\title{
Kommentar
}

\section{Om krokodiller og hodepine}

Få sykelige tilstander er mer utbredt enn hodepine. Ettårsprevalensen for hodepine for voksne er mer enn $50 \%$ (1), og i en norsk befolkning er det vist en ettårsprevalens for kronisk hodepine på hele 3,7\% (2). Historisk sett har den diagnostiske og terapeutiske tilnærmingen til denne svært vanlige lidelsen vært som for all rasjonell medisinsk praksis: Det gjelder å identifisere årsaken og rette behandlingen mot denne. I det gamle Egypt mente man at hodepine var forårsaket av overnaturlige krefter. Følgelig måtte behandlingen rette seg mot disse. En krokodille av leire, med korn i munnen, ble bundet til den sykes hode ved hjelp av et bånd med gudenes navn innskrevet (3). Den kjølende leiren må ha gitt en viss lindring, men særlig effektiv kan behandlingen neppe ha vært.

Pasienten i Müller \& Bekkelunds kasuistikk hadde hatt ensidig hodepine i over 18 år før endelig diagnose ble stilt. I den mellomliggende tiden hadde hun forsøkt en rekke medikamenter og behandlinger som i seg selv var rasjonelle nok, gitt de feilaktige diagnoser man hadde antatt. Diagnostiseringen ble ytterligere vanskeliggjort av at man en periode sannsynligvis hadde rett diagnose og behandling, som ble forlatt grunnet manglende behandlingsoppfølging. Problemet ble etter hvert det samme som for hodepinebehandlingen i det gamle Egypt: Når tilstandens reelle natur feiltolkes, blir heller ikke behandlingen særlig effektiv.
Som forfatterne er inne på, er det ikke uvanlig at primære hodepineformer feildiagnostiseres. Denne pasienten gikk sannsynligvis i tillegg over fra å ha hemicrania continua til å ha kronisk paroksysmal hemikrani. En slik transformasjon av tilstanden regnes ikke for å være vanlig. Kronisk paroksysmal hemikrani har på klinisk basis ofte vært sammenliknet med klasehodepine, noe som også gjenspeiles i de internasjonale klassifikasjonssystemene. Imidlertid konkluderer førstebeskriveren, Ottar Sjaastad, i en nylig publisert artikkel at likheten mellom de to genuint indometacinresponsive hodepinetypene, hemicrania continua og kronisk paroksysmal hemikrani, er mer påfallende (4). I tråd med dette er det i en nylig in vivo-studie beskrevet at indometacin, men ikke naproksen eller ibuprofen, hemmer nitrogenoksidindusert vasodilatasjon $i$ dura mater (5). Dermed kan man være på sporet av å forklare den absolutte effekten av indometacin på disse hodepinetypene.

Hodepineutredning og -behandling kan være vanskelig og langvarig, med store krav til utholdenhet fra både pasient og lege. Denne pasienten ble ufør av en i utgangspunktet behandlingsbar tilstand. Hvorvidt dette kunne ha vært unngått ved bedre diagnostisering og behandlingsoppfølging på et tidligere tidspunkt, kan vi ikke vite. Uansett illustrerer kasuistikken viktigheten av å revurdere årsaksforklaringen når behandlings- responsen uteblir. Da minsker risikoen for at behandlingen blir en leirekrokodille på pasientens hode.

\section{Are Brean}

are.brean@legeforeningen.no

Tidsskriftet

Oppgitte interessekonflikter: Ingen

\section{Litteratur}

1. Stovner LJ, Andree C. Prevalence of headache in Europe: a review for the Eurolight project. $J$ Headache Pain 2010; 11: 289-99.

2. Aaseth $\mathrm{K}$, Grande RB, Lundqvist $C$ et al. What is chronic headache in the general population? The Akershus study of chronic headache. Acta Neurol Scand Suppl 2009; 120: $30-2$

3. Silberstein SD, Lipton RB, Goadsby PJ. Headache in clinical practice. Oxford: Isis Medical Media, 1998

4. Sjaastad O, Vincent M. Indomethacin responsive headache syndromes: chronic paroxysmal hemicrania and Hemicrania continua. How they were discovered and what we have learned since. Funct Neurol 2010; 25: 49-55

5. Summ 0, Andreou AP, Akerman S et al. A potential nitrergic mechanism of action for indomethacin, but not of other COX inhibitors: relevance to indomethacin-sensitive headaches. J Headache Pain 2010; 11: 477-83

Mottatt 17.1. 2011 og godkjent 28.2. 2011.

Medisinsk redaktør Siri Lunde. 